\title{
Efficacy of biofeedback training in improving faecal incontinence and anorectal physiologic function
}

\author{
V Loening-Baucke
}

\begin{abstract}
The efficacy of biofeedback treatment on faecal incontinence and anorectal function was evaluated in eight patients with faecal incontinence treated with biofeedback training and medical therapy. Outcome and anorectal function were compared with nine faecal incontinent patients who received medical therapy alone. Three month follow up showed that $50 \%$ of patients in the biofeedback plus conventional treatment group and $56 \%$ of those treated conventionally only had improved. One year follow up showed that $13 \%$ in the biofeedback group were free of soiling and an additional $25 \%$ had improved. The results were similar in the conventionally treated group - $11 \%$ were free of soiling and an additional $44 \%$ improved. Anal pressures at rest and squeeze, the rectal distension volume that induced sustained inhibition of both the external and internal anal sphincter, and continence to rectally infused saline were significantly reduced in both groups of patients compared with controls $(p<0 \cdot 05)$. Biofeedback treatment had no effect on these abnormal anorectal functions in either patients who improved or those who did not. The improvement in faecal incontinence was probably due to medical intervention or regression of symptoms with time, or both, and not the result of biofeedback training.
\end{abstract}

Continence depends on the anal sphincters, the rectal reservoir, and the mechanisms that govern water and electrolyte transport in the gut and determine stool consistency. Faecal incontinence is defined as the inability to retain solid or liquid stool. Up to $80 \%$ of patients with faecal incontinence present without evidence of generalised neurological disorders or of other anorectal abnormalities, ${ }^{1}$ and this has been referred to as idiopathic faecal incontinence. ${ }^{2}$ Patients with idiopathic incontinence have lower sustained intra-anal squeeze pressures than normal control subjects and abnormal resting electromyographic activity in the external anal sphincter. ${ }^{3}$ Histological studies of the pelvic floor and the external sphincter have shown abnormalities which could be explained on the basis of partial denervation. ${ }^{4}$ This denervation injury is thought to be caused by chronic straining to defecate, child bearing, childbirth, or rectal prolapse.

In the past decade a new treatment, biofeedback, has been developed for a variety of illnesses. Biofeedback utilises the patient's self control over bodily functions. As a therapy for gastrointestinal disorders, biofeedback has been applied most successfully and extensively to patients with faecal incontinence. During biofeedback training the patient is provided instantly with information on the current function of the external anal sphincter by giving him or her visual or auditory information, or both, using an electronic device. This procedure is based on the assumption that the supposedly involuntary nature of some physiological responses and hence the impossibility of their self control stem from the poor afferent information from the anorectal continence mechanisms rather than irremedial defects in efferent information.

In a number of uncontrolled studies, biofeedback training has been reported to result in continence or a considerably reduced frequency of faecal incontinence in $73-80 \%$ of patients. ${ }^{5-11}$ Therapeutic gains seem to be maintained at one

TABLE I Characteristics of biofeedback treated incontinent patients and results of three month and one year follow up

\begin{tabular}{|c|c|c|c|c|c|c|c|c|c|c|c|c|c|}
\hline \multirow[b]{2}{*}{ Patient } & \multirow[b]{2}{*}{$\begin{array}{l}\text { Age } \\
\text { (yrs) }\end{array}$} & \multirow[b]{2}{*}{$\begin{array}{l}\text { Incontinence } \\
\text { (yrs) }\end{array}$} & \multirow[b]{2}{*}{$\begin{array}{l}\text { Frequency } \\
\text { of soiling }\end{array}$} & \multicolumn{3}{|c|}{ Incontinent of } & \multirow[b]{2}{*}{ Past history } & \multirow[b]{2}{*}{$\begin{array}{l}\text { Urinary } \\
\text { incontinence }\end{array}$} & \multirow[b]{2}{*}{$\begin{array}{l}\text { Gravl } \\
\text { para }\end{array}$} & \multicolumn{3}{|l|}{3 month follow up } & \multirow{2}{*}{$\begin{array}{l}\begin{array}{l}1 \text { year } \\
\text { follow up }\end{array} \\
\begin{array}{l}\text { Frequency } \\
\text { of soiling }\end{array}\end{array}$} \\
\hline & & & & $\begin{array}{l}\text { Formed } \\
\text { stool }\end{array}$ & $\begin{array}{l}\text { Diarrhoeal } \\
\text { stool }\end{array}$ & Gas & & & & Medications & $\begin{array}{l}\text { Subjective } \\
\text { outcome }\end{array}$ & $\begin{array}{l}\text { Frequency } \\
\text { of soiling }\end{array}$ & \\
\hline 1 & 35 & 2 & 3/day & & + & + & & Yes & $11 / 6$ & Modane fibre & $\begin{array}{l}\text { Improved, } \\
\text { decreased } \\
\text { diarrhoea }\end{array}$ & $2 / w k$ & $\begin{array}{l}\text { None, } \\
\text { diarrhoea } \\
\text { resolved }\end{array}$ \\
\hline 2 & 69 & 15 & $1 / \mathbf{w k}$ & Occ. & + & + & & Yes & $4 / 4$ & $\begin{array}{l}\text { Kaopectate } \\
\text { metamucil fibre }\end{array}$ & Improved & $0 \cdot 2 / \mathrm{wk}$ & $1 / w k$ \\
\hline 3 & 68 & 3 & Daily & Occ. & + & + & & Stress only & $3 / 3$ & Fibre & $\begin{array}{l}\text { Improved, } \\
\text { decreased } \\
\text { diarrhoea }\end{array}$ & $0 \cdot 5 / w k$ & $0 \cdot 5 /$ wk \\
\hline 4 & 51 & 4 & Daily & No & + & + & $\begin{array}{l}\text { Constipation } \\
\text { for } 28 \mathrm{yrs}\end{array}$ & No & $7 / 7$ & Fibre & $\begin{array}{l}\text { Improved, } \\
\text { decreased } \\
\text { diarrhoea }\end{array}$ & $1 / w k$ & $1 / w k$ \\
\hline 5 & 57 & 13 & $1-2 / w k$ & No & + & + & & No & $5 / 5$ & $\begin{array}{l}\text { Cholestyramine } \\
\text { imodium }\end{array}$ & Not improved & $1 / w k$ & $1-2 / w k$ \\
\hline 6 & 70 & 10 & $0-10 /$ day & Occ. & + & + & $\begin{array}{l}\text { Ant. resection } \\
\text { for rectal } \\
\text { prolapse }\end{array}$ & No & $0 / 0$ & $\begin{array}{c}\text { Metamucil } \\
\text { imodium }\end{array}$ & Not improved & $0-10 /$ day & Colostomy \\
\hline 7 & 76 & $0 \cdot 5$ & Daily & & + & + & & Yes & $5 / 4$ & $\begin{array}{c}\text { Metamucil } \\
\text { imodium }\end{array}$ & $\begin{array}{l}\text { Not improved, } \\
\text { decreased } \\
\text { diarrhoea }\end{array}$ & Daily & Daily \\
\hline 8 & 78 & 10 & $1 / w k$ & + & + & + & & Stress only & $3 / 3$ & Metamucil & Not improved & $1 / w k$ & $1 / w k$ \\
\hline
\end{tabular}

Pediatrics, University of

Dr V Loening-Bauck University of Pediatri and Clinics, Iowa City

Accepted for publication 2 February 1990 
TABLE II Characteristics of conventionally treated incontinent patients and results of three month and one year follow up

\begin{tabular}{|c|c|c|c|c|c|c|c|c|c|c|c|c|c|}
\hline \multirow[b]{2}{*}{ Patient } & \multirow[b]{2}{*}{$\begin{array}{l}\text { Age } \\
\text { (yrs) }\end{array}$} & \multirow[b]{2}{*}{$\begin{array}{l}\text { Incontinence } \\
\text { (yrs) }\end{array}$} & \multirow[b]{2}{*}{$\begin{array}{l}\text { Frequency } \\
\text { of soiling }\end{array}$} & \multicolumn{3}{|c|}{ Incontinent of } & \multirow[b]{2}{*}{ Past history } & \multirow[b]{2}{*}{$\begin{array}{l}\text { Urinary } \\
\text { incontinence }\end{array}$} & \multirow[b]{2}{*}{$\begin{array}{l}\text { Grav/ } \\
\text { para }\end{array}$} & \multicolumn{3}{|l|}{3 month follow up } & \multirow{2}{*}{$\begin{array}{l}1 \text { year follow } \\
\text { up } \\
\begin{array}{l}\text { Frequency } \\
\text { of soiling }\end{array}\end{array}$} \\
\hline & & & & $\begin{array}{l}\text { Formed } \\
\text { stool }\end{array}$ & Diarrhoea & Gas & & & & Medications & $\begin{array}{l}\text { Subjective } \\
\text { outcome }\end{array}$ & $\begin{array}{l}\text { Frequency } \\
\text { of soiling }\end{array}$ & \\
\hline 1 & 79 & $1 \cdot 8$ & $3-4 / w k$ & No & + & + & $\begin{array}{l}\text { Lifelong } \\
\text { constipation }\end{array}$ & Yes & $3 / 3$ & $\begin{array}{l}\text { Imodium } \\
\text { metamucil }\end{array}$ & Cured & None & None \\
\hline 2 & 68 & 5 & Daily & + & + & + & $\begin{array}{l}\text { Severe } \\
\text { constipation }\end{array}$ & No & $1 / 1$ & $\begin{array}{l}\text { Lomotil } \\
\text { metamucil }\end{array}$ & Improved & $2-3 / \mathrm{mth}$ & $2-3 / \mathrm{mth}$ \\
\hline $\begin{array}{l}3 \\
4\end{array}$ & $\begin{array}{l}84 \\
52\end{array}$ & $\begin{array}{l}4 \\
3\end{array}$ & $\begin{array}{l}0-3 / \text { day } \\
3-4 / \text { day }\end{array}$ & $\begin{array}{l}+ \\
+\end{array}$ & $\begin{array}{l}+ \\
+\end{array}$ & $\begin{array}{l}+ \\
+\end{array}$ & $\begin{array}{l}\text { Low ant. } \\
\text { resection } \\
\text { anastomosis } \\
10 \mathrm{~cm} \text { above } \\
\text { anus }\end{array}$ & $\begin{array}{l}\text { Stress only } \\
\text { No }\end{array}$ & $\begin{array}{l}3 / 3 \\
7 / 7\end{array}$ & Lomotil psyllium & $\begin{array}{l}\text { Improved } \\
\text { Improved }\end{array}$ & $\begin{array}{l}6 / \mathrm{mth} \\
3 / \mathrm{wk}\end{array}$ & $\begin{array}{l}6 / \mathrm{mth} \\
3 / \mathrm{wk}\end{array}$ \\
\hline 5 & 47 & 7 & $10 /$ day & + & + & + & $\begin{array}{l}\text { Bypass for } \\
\text { morbid } \\
\text { obesity }\end{array}$ & Yes & $5 / 5$ & & Improved & 1/day & 1/day \\
\hline $\begin{array}{l}6 \\
7\end{array}$ & $\begin{array}{l}73 \\
65\end{array}$ & $\begin{array}{l}4 \\
0 \cdot 8\end{array}$ & $\begin{array}{l}3 / \mathrm{wk} \\
6-7 / \mathrm{mth}\end{array}$ & + & $\begin{array}{l}+ \\
+\end{array}$ & $\begin{array}{l}+ \\
+\end{array}$ & $\begin{array}{l}\text { Subtotal } \\
\text { colectomy } \\
\text { for } \\
\text { diverticulitis }\end{array}$ & $\begin{array}{l}\text { Stress only } \\
\text { Yes }\end{array}$ & $\begin{array}{l}3 / 3 \\
0 / 0\end{array}$ & $\begin{array}{l}\text { Codeine } \\
\text { metamucil } \\
\text { imodium }\end{array}$ & $\begin{array}{l}\text { Not improved } \\
\text { Not improved }\end{array}$ & $\begin{array}{l}2-3 / \text { wk } \\
6-7 / \mathrm{mth}\end{array}$ & $\begin{array}{l}2-3 / \mathrm{wk} \\
6-7 / \mathrm{mth}\end{array}$ \\
\hline 8 & 75 & 10 & $3-4 /$ day & & + & + & $\begin{array}{l}\text { Cervical } \\
\text { cancer and } \\
\text { irradiation } \\
30 \text { yrs ago }\end{array}$ & & $3 / 3$ & Metamucil & Not improved & 4/day & $5 /$ day \\
\hline 9 & 49 & $0 \cdot 5$ & 20/day & + & + & + & $\begin{array}{l}\text { Cervical } \\
\text { cancer and } \\
\text { irradiation } 6 \\
\text { yrs ago }\end{array}$ & No & $1 / 1$ & Cholestyramine & Not improved & 20/day & Colostomy \\
\hline
\end{tabular}

to two year follow up. The mechanisms for the improved continence are not known, since only a few studies reported anorectal manometric measurements before and after biofeedback treatment.

The aims of the present study were to evaluate: (1) the efficacy of biofeedback treatment (a) by evaluating outcome in patients with faecal incontinence treated with biofeedback training and medical therapy and (b) by comparing the outcome of the biofeedback treated patients to that in a consecutive group of faecal incontinent patients treated with medical therapy alone; and (2) the effects of biofeedback treatment on anorectal function by comparing anorectal manometric measurements before and after biofeedback treatment.

\section{Methods}

SUBJECTS

The study population consisted of 17 women aged 35-84 years (mean 64 years) who complained of faecal incontinence. All experienced incontinence with diarrhoeal stools and $59 \%$ also with formed stools (see Tables I and II). Eight women with faecal incontinence (aged 35 to 78 years, mean 63 years) received biofeedback treatment consisting of three one hour training sessions, and performed daily anal exercises (Kegle exercises) for three months. In addition, these eight received medical treatment to improve stool consistency. One control group consisted of nine female patients with faecal incontinence (aged 47 to 84 years, mean 66 years) who recieved only medical therapy to improve stool consistancy and faecal incontinence. All patients with faecal incontinence were seen in the Gastroenterology and Gastrointestinal Surgery Clinics at the University of Iowa. Patients receiving biofeedback were evaluated from September 1983 to August 1985, and the control group were consecutively evaluated from September 1985 to June 1987. Patients were enrolled if they experi- enced faecal incontinence at least once a week. Patients with a disruption of the anal sphincter due to birth trauma or surgery to the anal canal (fissurectomy or fistulectomy) and patients with generalised neurological or muscular disease were not enrolled. Four additional incontinent women were excluded. They elected not to return for a second and third biofeedback session for the following reasons: one felt unable to travel because of 10 incontinent episodes per day, one did not think biofeedback training would help, and two patients with Crohn's disease of the colon underwent colectomy and ileostomy (even so one experienced improvement after the first session). Some of the patients included in the faecal incontinent control group suffered from gastrointestinal disease causing diarrhoea, but had no involvement of the anal canal. The characteristics of the faecal incontinent patients are presented in Tables I and II.

The anorectal physiological data obtained on the biofeedback group were also compared with those of 11 healthy control women ( 30 to 81 years of age, mean 64 years). These 11 were selected because of age from a group of 18 healthy women who were studied previously. ${ }^{12}$ They had two bowel movements per day to one every other day. They had no history of previous gastrointestinal disease and their physical examination yielded normal results.

The study was approved by the Institutional Human Research Review Committee. Written informed consent was obtained from all biofeedback subjects and controls.

\section{STUDY DESIGN}

A complete history and physical examination were performed on all subjects and the frequency and consistency of bowel movements and soiling episodes were determined from the stool recordings of the past month. Patients kept diaries of faecal soiling and bowel movements for an additional three months. Anorectal manometry and saline continence test were performed at 


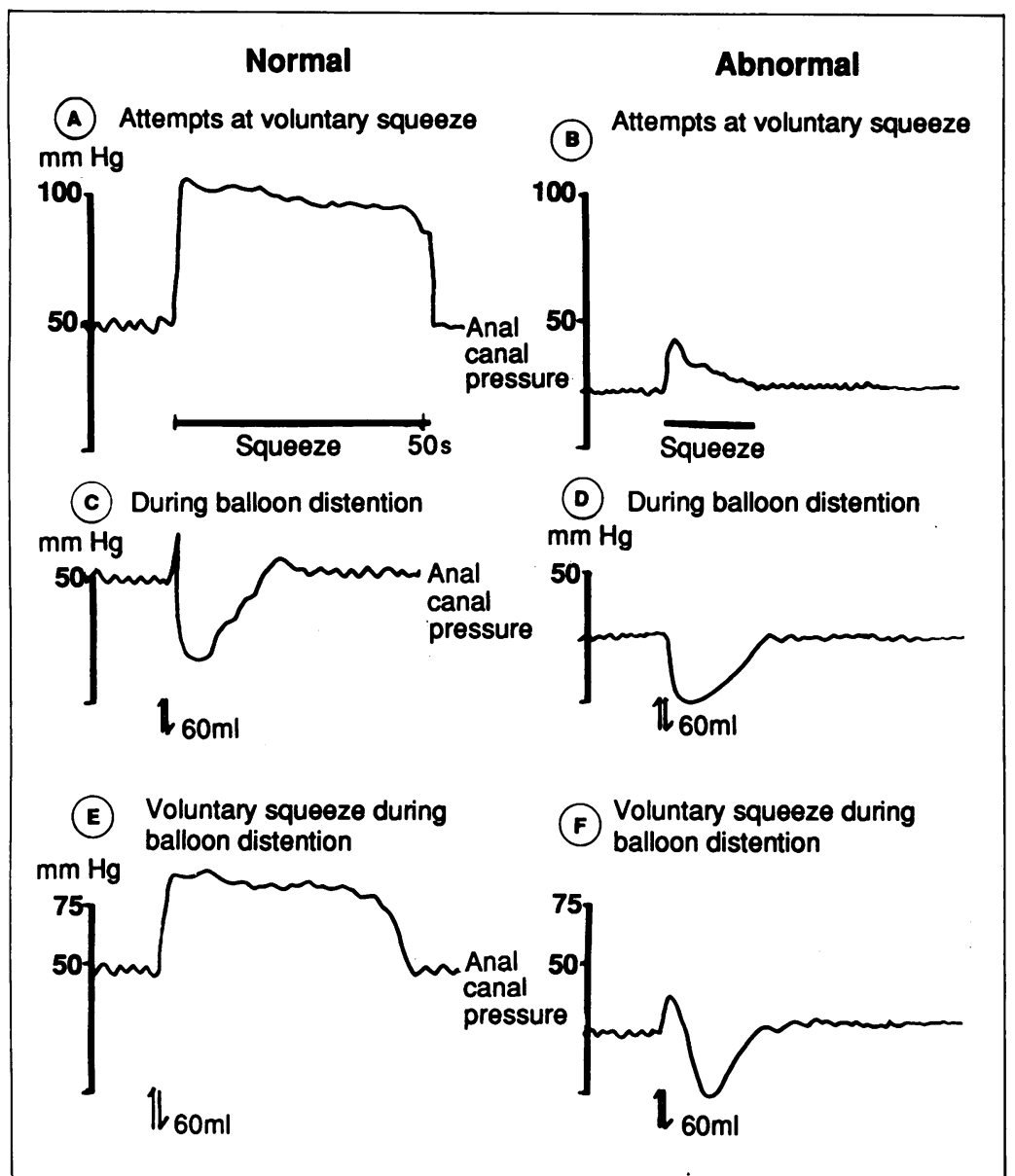

Figure 1: Intraluminal pressure recordings from the anal canal during rectal balloon distension with $60 \mathrm{ml}$ air for 1-2 seconds. A healthy person is able to voluntarily contract the external anal sphincter $(A)$, has a reflex contraction of the external anal sphincter before the reflex relaxation of the internal anal sphincter after balloon distension $(C)$, and can override the reflex relaxation when balloon distension is perceived $(E)$. A patient with weak anal sphincter can accomplish only a weak and short voluntary contraction of the external anal sphincter $(B)$, has no reflex contraction of the external anal sphincter after balloon distension $(D)$, and is unable to override the reflex relaxation when told to squeeze as soon as rectal distension is perceived $(F)$.

the beginning of the study in all subjects and repeated an average two months later in patients doing daily anal exercises and receiving the three biofeedback sessions. Three months and 12 months after the initial anorectal evaluation all patients were asked to fill out a follow up questionnaire which included questions on medication use, stooling patterns, and frequency of soiling.

\section{BIOFEEDBACK TREATMENT}

Three one hour long biofeedback sessions were given using a three balloon system developed by Schuster et al. ${ }^{13}$ Biofeedback treatment involved measuring internal sphincter relaxation and external sphincter contraction by recording pressure changes in two intra-anal balloons and using a third balloon for rectal distension. Biofeedback treatment incorporated three separate and potentially effective components: exercise of the external sphincter muscle; training in discrimination of rectal sensations; and training synchrony of the internal and external sphincter responses to rectal distension. ${ }^{6}$ During biofeedback the patient was made aware of the abnormal -weak or absent pressure increase during voluntary anal sphincter contraction, of rectal sensations during distension, and of absent or weak external sphincter contraction before internal sphincter relaxation. All this was visualised during the anorectal manometric recording. The patients were also shown a tracing from a normal person (Fig l(A), (C), (E)) to demonstrate the missing or weak voluntary external sphincter/ pelvic floor contraction (Fig 1(B)), the missing reflex contraction during rectal distension (Fig 1(D)), and the inability to override reflex relaxation of the internal sphincter with external sphincter squeeze (Figure $1(F)$ ). The patients were instructed to contract the voluntary anal sphincter (varying muscles in the anal area which surround the anal canal, such as the external anal sphincter, puborectalis muscle, and the muscles of the pelvic floor. Constant visual (by recording) and verbal (by the technician) reinforcements were given when correct responses were made, and the patients were encouraged to try harder or to modify their efforts in order to produce tracings similar to normal tracings in approximately 50 training trials per session. In addition, rectal balloon distension volumes large enough to be felt by the patients were used in an effort to train the patients to recognise smaller and smaller distension volumes and to synchronise voluntary anal sphincter contraction with balloon distension. The patients were encouraged to increase the amplitude and duration of the voluntary anal sphincter response. In some patients an abnormal increase in intra-abdominal pressure during attempted anal squeeze was recorded. These patients were instructed to inhibit the intra-abdominal pressure increase. As training proceeded, trials in which control was tested in the absence of biofeedback were introduced to encourage the development of autonomous self control.

\section{CONVENTIONAL THERAPY}

Conventional medical treatment consisted of fibre, psyllium, loperamide (Imodium), diphenoxylate hydrochloride with atropine sulphate (Lomotil), cholestyramine, etc (see Tables I and II). Many patients were receiving conventional medical treatment at the time of their first evaluation. Conventional treatment was adjusted during the follow up visits to further improve consistency and frequency of stooling by the patient's personal physician.

\section{MEASUREMENTS}

Subjective measurement. Subjective measurement of continence was obtained from the stool diaries and pretreatment and follow up questionnaires. A good treatment response (improvement and cure of incontinence) was defined as the disappearance of soiling or $\mathrm{a} \geq 75 \%$ improvement in the frequency of soiling three and 12 months after the study began..$^{74}$

Objective measurements. Objective measurements were obtained through anorectal manometric evaluation and saline continence test, done once in healthy controls and faecal incontinent controls and twice in the biofeedback treated faecal incontinent patients. These patients were re-evaluated on the day of the third biofeedback training session. The battery of 
anorectal tests was repeated four or more hours after the biofeedback session so that the anal muscles had time to recover from the training in the morning.

The instrument used for the anorectal manometric evaluation was a motility probe (model P31-D3, Sandhill Scientific, Littleton, Colorado, USA). ${ }^{15} 16$ This was a flexible, silicone rubber tube ( $5 \mathrm{~mm}$ in diameter) that contained three intraluminal transducers spaced $5 \mathrm{~cm}$ apart at the distal end. A latex balloon was attached to the end of a thin polyethylene tube and was tied to the tip of the motility probe, $5 \mathrm{~cm}$ above the distal end. Pressure from the latex balloon was transmitted via the polyethylene tube to a pressure transducer (Statham PDS, Statham Instruments, Oxford, California, USA). The output of all four transducers were fed into a dynograph recorder (R611, SensorMedics, Anaheim, California, USA).

The manometric studies were performed with the subjects lying on their left side and the hips and knees flexed. The anal resting pressure and maximal squeeze pressure were determined during step wise retraction of $1 \mathrm{~cm}$ every two minutes of one intraluminal pressure transducer of the motility probe from the rectum through the anal canal. The anal resting pressure was defined as the pressure $(\mathrm{mmHg})$ at the troughs of the waves. The highest anal resting pressure was located $2 \mathrm{~cm}$ above the anal verge. The maximal squeeze pressure $(\mathrm{mmHg})$ was the highest pressure measured above anal resting pressure. We defined a squeeze as a pressure increase in the anal canal without intra-abdominal pressure increase. Anal pullthrough pressure was measured by rapidly pulling $(1 \mathrm{~cm} / 1$ second) the three intraluminal transducers from the rectum through the anal canal while the subject was resting and also during voluntary squeeze. The anal pullthrough pressure was defined as the pressure difference in $\mathrm{mmHg}$ between the peak of the curve on the pressure tracing and atmospheric pressure, and was calculated for each subject as the average of six measurements at rest and as the average of the three highest measurements during voluntary squeeze.

The effect of rectal distension on anal pressure was assessed with the base of the latex balloon lying $12 \mathrm{~cm}$ above the anal verge and the pressure transducer lying in the anal canal in the area with the highest pressure (approximately $2 \mathrm{~cm}$ above the anal verge). The threshold of the rectosphincteric reflex and the threshold of rectal sensation ( $\mathrm{ml}$ air) were determined three times by inflating the balloon transiently for 1 second in random order with $60,50,40,30,25,20,15$, 10 , and $5 \mathrm{ml}$ of air with a graduated syringe, starting each time at 0 . The threshold of the rectosphincteric reflex was the smallest air volume that produced a $5 \mathrm{mmHg}$ or greater decrease in anal pressure. The air volume when two of the three inflations were felt was defined as the threshold of rectal sensation. The critical volume, the minimal amount of air $(\mathrm{ml})$ felt as a lasting urge to defecate and the volume of constant relaxation, the rectal distension volume which produced a sustained complete relaxation of the internal and external anal sphincter were determined by step wise adding $30 \mathrm{ml}$ air each 20 seconds into the rectal balloon. When the critical volume had been reached, but constant relaxation had not occurred, the next highest volume was used as the volume of constant relaxation.

For objective measurement of overall continence the saline continence test ${ }^{17}$ was done immediately after the manometric evaluation. A small catheter was placed into the distal bowel with its tip positioned $10 \mathrm{~cm}$ from the anal verge. Saline maintained at $37^{\circ} \mathrm{C}$ was infused into the distal bowel at a rate of $60 \mathrm{ml} / \mathrm{minute}$ up to $780 \mathrm{ml}$, while the subjects sat upright in a specially designed chair with a central round aperture. Any leakage was collected by means of a funnel and collecting cylinder which sat on top of a weight transducer. The signal from the weight transducer was fed into the dynograph recorder. The volume infused into the rectum when leakage of $\geq 10 \mathrm{ml}$ saline first occurred was measured (leak volume). In subjects with no leakage a value of $780 \mathrm{ml}$ saline was used for the analysis.

Statistical analysis. The Wilcoxon non-paired rank sum test, Wilcoxon signed rank sum test, and Fisher's exact probability test were used.

\section{Results}

The clinical characteristics of patients treated with biofeedback, daily anal exercises, and medical therapy can be seen in Table I, and those of patients treated with medical therapy alone are listed in Table II. All eight patients in the biofeedback treated group experienced faecal incontinence with diarrhoea, four of six complained of incontinence with formed stools, while two patients had no formed bowel movements. All nine patients in the faecal incontinent conventionally treated group experienced faecal incontinence with diarrhoea, six of seven complained of incontinence with formed stools, and two patients had no formed bowel movements. Patients in both groups were similar in age.

\section{EFFICACY OF BIOFEEDBACK FOR FAECAL} INCONTINENCE

Three month follow up (Tables I and II). None of the eight patients who had received biofeedback treatment were free of soiling; four patients (50\%) reported improvement and four (50\%) reported no change in the frequency of soiling one month after biofeedback training was completed. Three months after the initial manometric evaluation one of the nine conventionally treated patients was free of soiling and four reported improvement $(56 \%)$, while four patients $(44 \%)$ reported no change in the frequency of soiling. Three months after the initial manometric evaluation biofeedback plus conventional treated patients did not differ in improvement in soiling frequency to patients receiving conventional therapy alone.

One year follow up (Tables I and II). One year after the initial evaluation only one of the eight biofeedback treated patients had no soiling and two had improved (38\%), four had no reduction in the frequency of soiling, and one patient had undergone colostomy to obtain relief from soiling. One of the conventionally treated patients 
Figure 2: Highest anal resting pressure, maximal anal squeeze pressure, and anal pullthrough pressures at rest and during squeeze in patients before and after biofeedback treatment, in comparison with healthy control subjects and conventionally treated faecal incontinent control subjects.
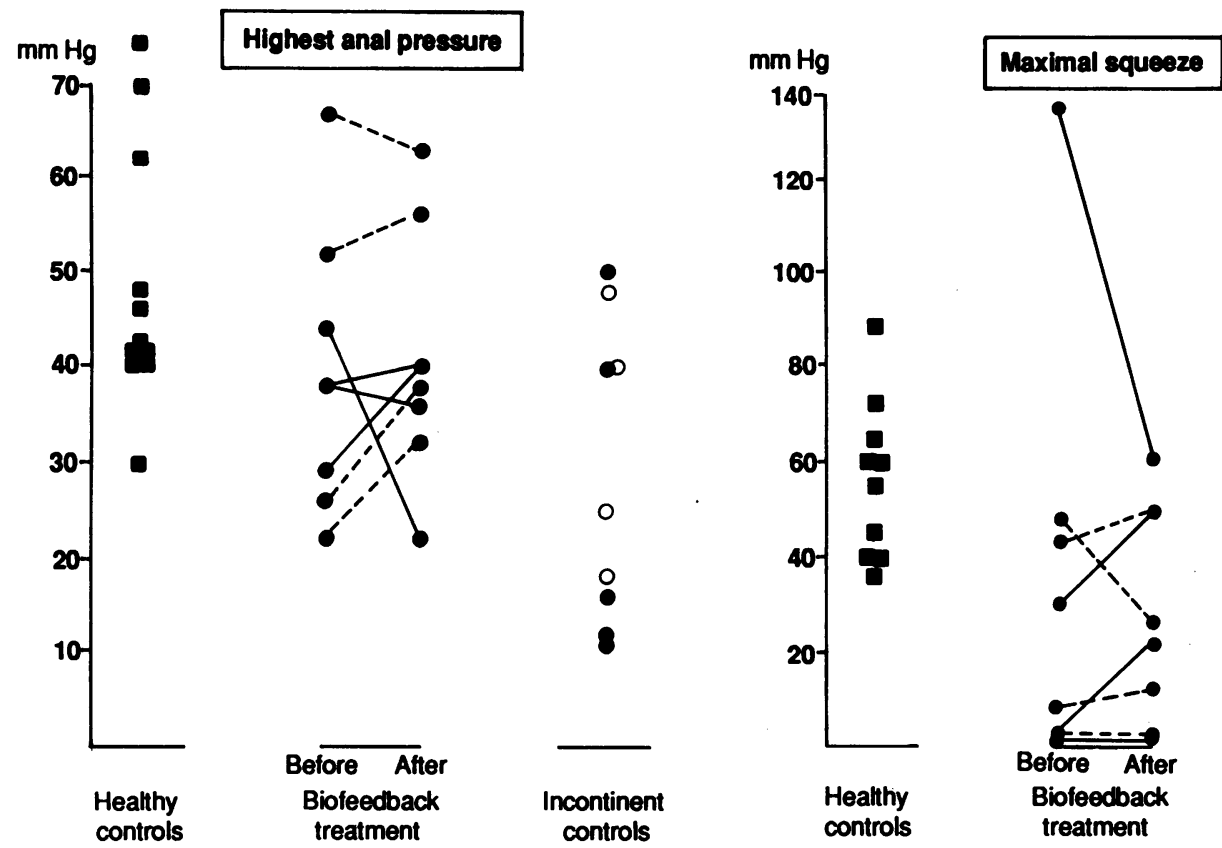

政

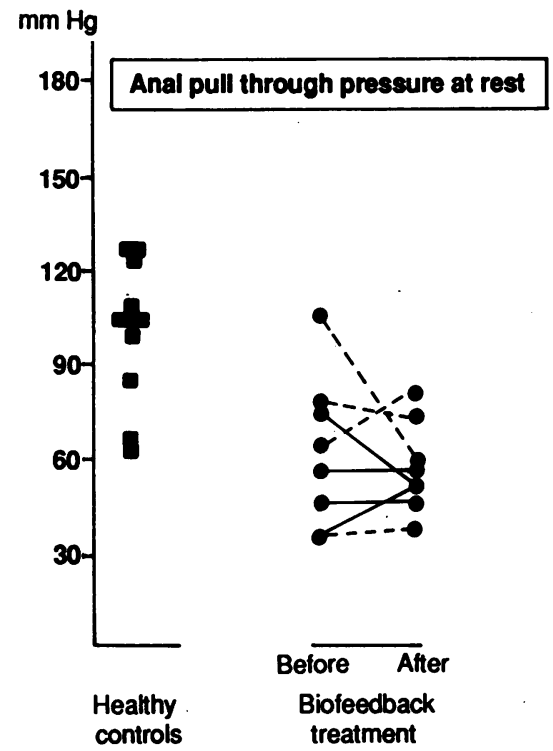

\section{Biofeedback}

- Good clinical response

- - - Poor clinical response

Incontinent controls

- Good clinical response

- Poor clinical response

continued to be free of soiling, four were improved (56\%), three had no reduction in the frequency of soiling, and one had undergone colostomy. This patient had developed a sigmoid stricture because of irradiation. One year after the initial manometric anorectal evaluation patients who had received biofeedback training in addition to conventional treatment had no better outcome than patients treated with conventional therapy alone. treated patients had no improvement in mean (SD) highest anal resting pressure (before treatment 40 (15), afterwards 41 (13) $\mathrm{mmHg}$ ) maximal squeeze pressure (before 34 (46), afterwards 28 (23) $\mathrm{mmHg}$ ), and anal pullthrough pressure at rest (before 62 (26), afterwards 57 (14) $\mathrm{mmHg}$ ) and during squeeze (before 91 (42), afterwards 89 (35) $\mathrm{mmHg}$ ) after biofeedback treatment and daily anal exercises. There was no significant difference for these anal pressure measurements before and after biofeedback training in the four patients who improved and the four patients who did not (see Fig 2 and Table III). Biofeedback treated patients had significantly lower maximal squeeze pressures 
TABLE III Mean (SD) anal measurements in healthy controls and improved and unimproved patients before and after biofeedback training and faecal incontinent controls

\begin{tabular}{|c|c|c|c|c|c|c|c|}
\hline & \multirow[b]{3}{*}{$\begin{array}{l}\text { Healthy } \\
\text { controls } \\
(n=11)\end{array}$} & \multicolumn{4}{|c|}{ Biofeedback treated patients } & \multicolumn{2}{|c|}{$\begin{array}{l}\text { Faecal incontinent } \\
\text { controls }\end{array}$} \\
\hline & & \multicolumn{2}{|c|}{ Improved } & \multicolumn{2}{|c|}{ Not improved } & \multirow[b]{2}{*}{ 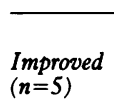 } & \multirow{2}{*}{$\begin{array}{l}\text { Not } \\
\text { improved } \\
(n=4)\end{array}$} \\
\hline & & $\begin{array}{l}\text { Before } \\
(n=4)\end{array}$ & $\begin{array}{l}\text { After } \\
(n=4)\end{array}$ & $\begin{array}{l}\text { Before } \\
(n=4)\end{array}$ & $\begin{array}{l}\text { After } \\
(n=4)\end{array}$ & & \\
\hline \multirow{3}{*}{$\begin{array}{l}\text { Highest anal resting tone (mmHg) } \\
\text { Maximal squeeze pressure (mmHg) } \\
\text { Anal pullthrough pressure at rest } \\
\text { (mmHg) } \\
\text { Anal pullthrough pressure during } \\
\text { squeeze (mmHg) }\end{array}$} & $\begin{array}{l}49(14) \\
56(17)\end{array}$ & $\begin{array}{l}37(6) \\
42(64)\end{array}$ & $\begin{array}{l}35(9) \\
33(27)\end{array}$ & $\begin{array}{l}42(21) \\
25(25)\end{array}$ & $\begin{array}{l}47(15) \\
22(21)\end{array}$ & $\begin{array}{l}26(18) \\
22(8)\end{array}$ & $\begin{array}{l}33(14) \\
45(40)\end{array}$ \\
\hline & $101(22)$ & $53(17)$ & $51(4)$ & $74(35)$ & $63(18)$ & Not done & Not done \\
\hline & $148(29)$ & $82(32)$ & $71(20)$ & $102(57)$ & $106(41)$ & Not done & Not done \\
\hline
\end{tabular}
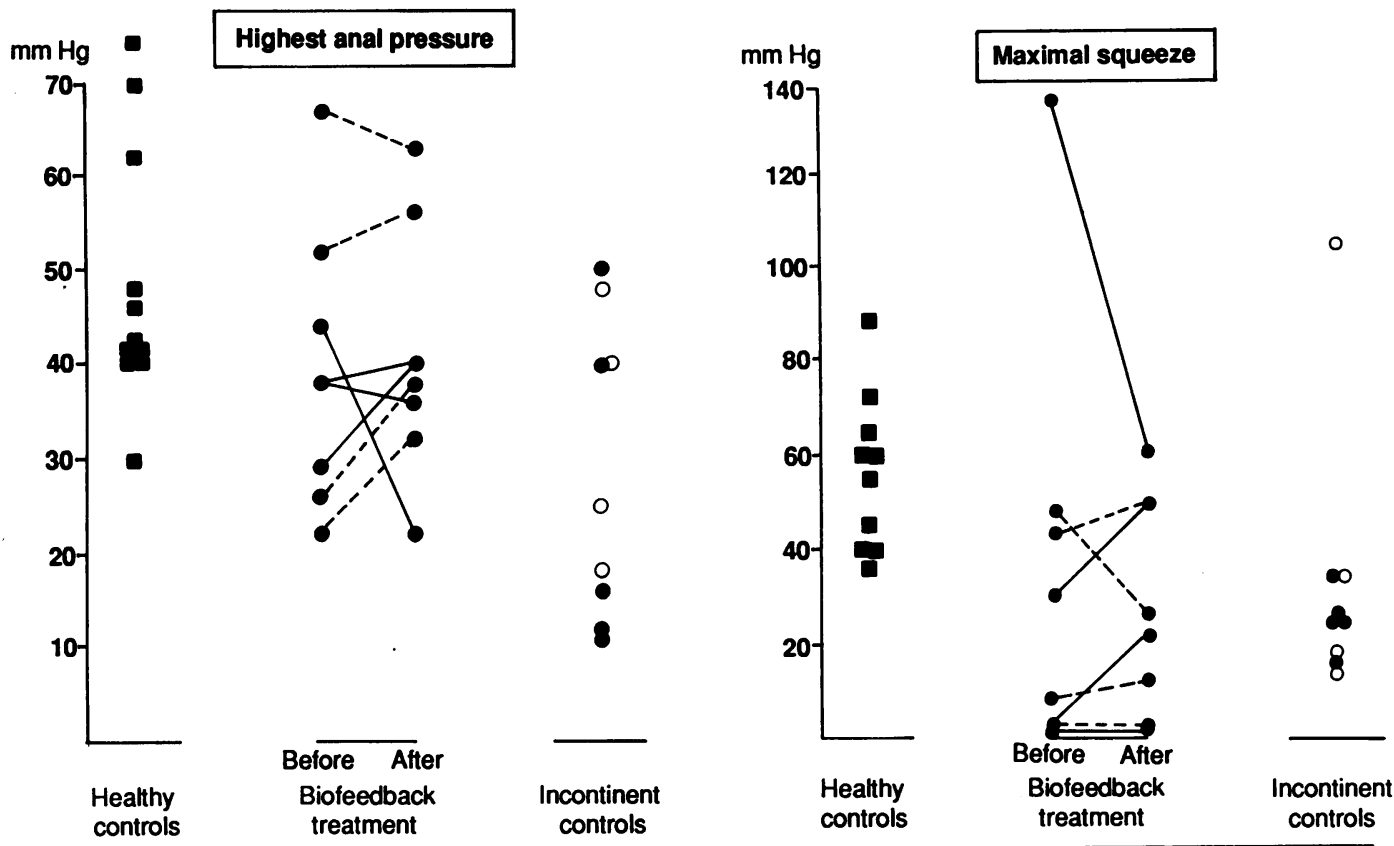

$\mathrm{mm} \mathrm{Hg}$
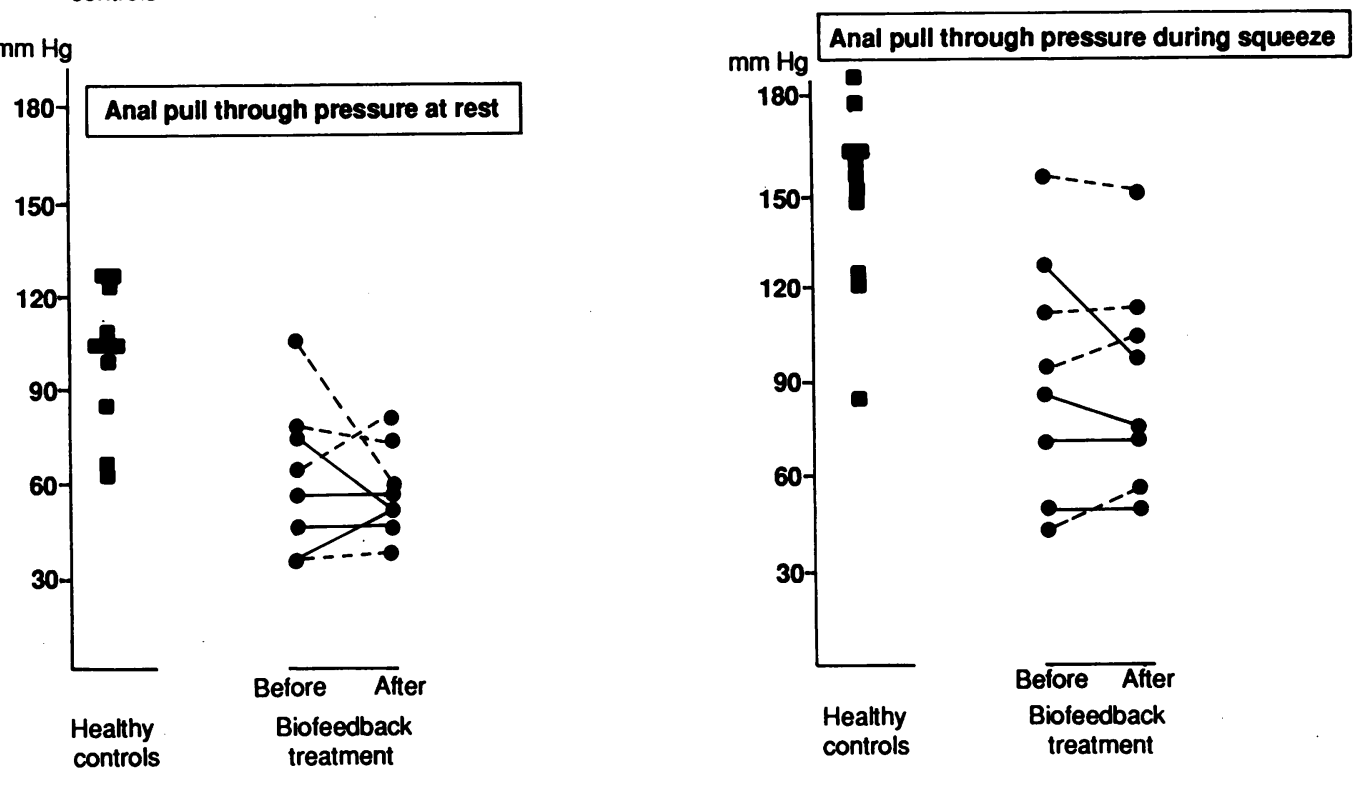

Biofeedback

$\longrightarrow$ Good clinical response

- - Poor clinical response

Incontinent controls

- Good clinical response

- Poor clinical response

Figure 3: Threshold of rectal sensation, critical volume, volume of constant relaxation, and saline volume when $\geq 10 \mathrm{ml}$ leaked in patients before and after biofeedback treatment, in comparison with healthy control subjects and conventionally treated faecal incontinent control subjects. 
TABLE IV Effects of rectal balloon distension and saline continence test in healthy controls and improved and not improved patients before and after biofeedback training and faecal incontinent controls (mean (SEM))

\begin{tabular}{|c|c|c|c|c|c|c|c|}
\hline & \multirow{3}{*}{$\begin{array}{l}\text { Healthy } \\
\text { controls } \\
(n=11)\end{array}$} & \multicolumn{4}{|c|}{ Biofeedback treated patients } & \multicolumn{2}{|c|}{$\begin{array}{l}\text { Faecal incontinent } \\
\text { controls }\end{array}$} \\
\hline & & \multicolumn{2}{|l|}{ Improved } & \multicolumn{2}{|c|}{ Not improved } & \multirow[b]{2}{*}{$\begin{array}{l}\text { Improved } \\
(n=5)\end{array}$} & \multirow{2}{*}{$\begin{array}{l}\text { Not } \\
\text { improved } \\
(n=4)\end{array}$} \\
\hline & & $\begin{array}{l}\text { Before } \\
(n=4)\end{array}$ & $\begin{array}{l}\text { After } \\
(n=4)\end{array}$ & $\begin{array}{l}\text { Before } \\
(n=4)\end{array}$ & $\begin{array}{l}\text { After } \\
(n=4)\end{array}$ & & \\
\hline \multicolumn{8}{|l|}{$\begin{array}{l}\text { Rectal distension volume } \\
\text { (ml air) }\end{array}$} \\
\hline $\begin{array}{l}\text { Rectosphincteric reflex } \\
\text { Threshold sensation } \\
\text { Critical volume }\end{array}$ & $\begin{array}{l}18(8) \\
14(9) \\
157(78)\end{array}$ & $\begin{array}{c}10(4) \\
21(5) \\
120(49)\end{array}$ & $\begin{array}{l}13(6) \\
21(13) \\
95(33)\end{array}$ & $\begin{array}{l}20(14) \\
20(5) \\
93(40)\end{array}$ & $\begin{array}{r}24(24) \\
28(10) \\
100(42)\end{array}$ & $\begin{array}{c}25(17) \\
27(8) \\
106(67)\end{array}$ & $\begin{array}{c}23(3) \\
31(19) \\
105(17)\end{array}$ \\
\hline $\begin{array}{l}\text { Volume of constant } \\
\text { relaxation } \\
\text { Leak volume (ml saline) }\end{array}$ & $\begin{array}{l}192(80) \\
553(235)\end{array}$ & $\begin{array}{c}83(45) \\
113(109)\end{array}$ & $\begin{array}{c}85(29) \\
135(105)\end{array}$ & $\begin{array}{c}55(26) \\
115(120)\end{array}$ & $\begin{array}{r}113(62) \\
98(75)\end{array}$ & $\begin{array}{r}108(86) \\
78(63)\end{array}$ & $\begin{array}{l}88(57) \\
79(48)\end{array}$ \\
\hline
\end{tabular}

and anal pullthrough pressures at rest and during squeeze than the healthy controls $(\mathrm{p}<0.05)$. Biofeedback treated patients were not significantly different from conventionally treated patients in mean anal resting pressure or maximal squeeze pressure. Anal pullthrough pressures at rest and during squeeze were not measured in the conventionally treated patients.

Effects of rectal balloon distension (Table IV and Fig 3). Biofeedback treated patients had no improvement in the minimal rectal distension volumes required to produce a rectosphincteric reflex (before treatment 15 (11), afterwards 18 (18) $\mathrm{ml}$ ), threshold of rectal sensation (before 21 (4), afterwards $24(11) \mathrm{ml}$ ), an urge to defecate (critical volume (before 106 (44), afterwards 98 (35) $\mathrm{ml}$ ), or complete sustained inhibition of both the internal and external anal sphincters (before 69 (37), afterwards $99(47) \mathrm{ml})$. There was no significant difference in these distension tests before and after biofeedback training in the four patients who improved and the four who did not (Fig 3 and Table IV). Biofeedback treated patients were not significantly different from conventionally treated patients in these distension volumes. The volume at which constant relaxation of both sphincters occurred was significantly reduced in the eight biofeedback treated patients (before treatment 69 (37), afterwards $99(47) \mathrm{ml}$ ) and the faecal incontinent control subjects $(99(71) \mathrm{ml})$ as compared with controls $(192(80) \mathrm{ml})(\mathrm{p}<0.05)$. In none of the healthy control subjects did constant relaxation occur before feeling a strong urge to defecate, while constant relaxation occurred in five of eight patients in the biofeedback group $(p<0.01)$ and in four of nine patients in the conventionally treated group $(\mathrm{p}<0.03)$ before feeling a strong urge.

Saline continence test (Table IV and Fig 3). Biofeedback treated patients were not able to retain a significantly larger mean volume of saline without leakage after biofeedback training. There was no significant difference for the leak volume before and after biofeedback training in the four patients who improved and the four who did not improve (Fig 3 and Table IV). Biofeedback treated patients (before treatment $114(106) \mathrm{ml}$, afterwards $116(87) \mathrm{ml}$ ) and faecal incontinent control subjects $(78(53) \mathrm{ml})$ leaked at significantly lower mean saline volumes than control subjects $(553(235) \mathrm{ml})(\mathrm{p}<0 \cdot 01)$.

\section{Discussion}

This study did not show that biofeedback treatment is effective in our patients with faecal incontinence. Three month and one year follow up showed that faecal incontinent patients treated with biofeedback, sphincter exercises, and conventional therapy did not differ in improvement of soiling from incontinent patients treated with conventional therapy alone. Biofeedback treatment did not improve abnormal anorectal physiologic function including anal pressure at rest, squeeze pressure, sustained relaxation of the internal and external sphincter with decreased volumes of rectal distension, and continence to rectally infused saline in those patients who improved with biofeedback treatment.

A patient with faecal incontinence often will seek treatment at a time of increased frequency of soiling, and a measurement of the intensity of the symptoms at this point does not reflect the true state over time. In most cases, if untreated, the symptom tends to recede (regression to the mean). In addition, a simple comparison of preand posttreatment frequency of soiling can be misleading, in particular, if treatment is stopped when the symptoms have disappeared or greatly lessened. To overcome this problem we evaluated a control patient group and evaluated both patient groups at preset times. Ideally, patients with faecal incontinence should have been randomly assigned to conventional therapy or biofeedback plus conventional therapy instead of the consecutive enrolment in our study.

We defined our patient population to allow assessment of the efficacy of these treatments on faecal incontinence. We excluded patients with faecal incontinence caused by meningomyelocele or disruption of the sphincter (birth trauma or surgical intervention) because these underlying problems have been reported to relate to poor outcome, particularly in the presence of diarrhoea.

Whitehead et $a l^{11}$ reported treatment results in 13 geriatric patients with incontinence to solid stools. Daily sphincter exercises for one month in $50 \%$ of them did not produce clinical improvement and did not significantly increase the strength of sphincter contractions. Biofeedback training did significantly augment sphincter strength; $60 \%$ of patients were improved at six months and $42 \%$ at one year.

Our biofeedback training technique was 
similar to that in other studies, ${ }^{5-8111418}$ but our study population may have been different from those in a number of uncontrolled biofeedback training studies which have reported that $70-83 \%$ of patients achieved continence or considerably reduced frequency of incontinence..$^{5-10}$ In some of these studies, patients had incontinence to solid stools only, ${ }^{611}$ but some patients were also incontinent of liquid stool ${ }^{5-10}$ or liquid stool only. ${ }^{7}$ The different success rate may be due to our different patient population. Our patients all complained of faecal incontinence with liquid stools. Four patients in the biofeedback group and six in the conventionally treated group also had stool incontinence with formed stools.

Biofeedback therapy is often combined with additional treatments and it may be these that are responsible for the decrease in the frequency of soiling through improvement or resolution of diarrhoea. In support of our findings, small controlled studies in faecal incontinent adults ${ }^{19} 20$ and children with faecal incontinence due to meningomyelocele ${ }^{1821}$ showed that biofeedback treatment was not significantly better than sphincter exercises, ${ }^{19}$ dietary adjustment, ${ }^{19}$ expectancy of improvement, conventional therapy including regulating bowel habits by frequent toilet use after meals, adjusting stool consistency with drugs, and follow up attention ${ }^{21}$ or behaviour modification therapy. ${ }^{18}$

There are at least three components to biofeedback treatment: exercise of the external sphincter muscle; training in discrimination of rectal sensations; and training synchrony of the internal and external sphincter responses during rectal distension. Each of these components may be effective for some patients. It is possible, for example, that patients who have an impaired external sphincter muscle (perhaps due to previous injury at childbirth or surgery) and normal rectal sensation will respond to exercise so that reflexive response to rectal distension will be adequate. On the other hand, patients with a raised sensory threshold to rectal distension (perhaps due to multiple sclerosis or other neurological disorders) may respond by learning to sense smaller volumes of rectal distension. There are still other patients who have adequate sensation and muscular strength, but no appropriate synchrony of the sphincteric response.

The use of objective and sensitive assessment instruments is essential in the evaluation of biofeedback treatment results. Only a few studies reported anorectal manometric measurements before and after biofeedback. Wald ${ }^{7}$ used the three balloon system ${ }^{13}$ for anorectal manometric assessment and found no significant difference after biofeedback training in the thresholds of rectal sensation and internal sphincter relaxation between faecal incontinent patients with good and poor outcome. The threshold of reflexive external sphincter contraction decreased significantly in patients with good and poor outcome. Riboli et $a l^{10}$ used an hour-glass shaped device consisting of continuous water perfused catheters for anorectal evaluation. In patients with good outcome, the anal resting pressure increased from 15 (9) to 40 (12) $\mathrm{mmHg}$ (normal $52(5)$ ), the voluntary external sphincter squeeze increased from $32(9)$ to $67(28) \mathrm{mmHg}$ (normal $110(10)$ ), and the threshold of rectal sensation decreased from 65 (4) to 28 (7) $\mathrm{ml}$ air (normal 60 (5)). Patients with unsatisfactory outcome also had increased anal resting pressure and voluntary external sphincter squeeze, and decreased threshold of rectal sensation. ${ }^{10}$ Latimer et $a l^{20}$ found that after biofeedback treatment the rectosphincteric reflexes remained abnormal despite achievement of continence.

Our study did not show a better clinical outcome after biofeedback treatment. No improvement of anorectal function was observed. Therefore, the improved continence observed in some of our patients may be the result of medical intervention or spontaneous regression of symptoms, or both, and not of biofeedback training. Patients with incontinence and diarrhoea did not seem to benefit from biofeedback training.

Part of this work was presented at the American Motility Society Meeting in October 1986 at Houston, Texas, USA and was published in abstract form in Gastroenterology 1986; 91: 1060. The author thanks Ms Molly Wiese and Mrs Cassie Savage for excellent technical assistance.

1 Penninckx FM, Elliot MS, Hanke E, et al. Faecal incontinence. Int 7 Colorect Dis 1987; 2: 173-86.

2 Swash $M$. The neuropathology of idiopathic faecal incontinence. In: Thomas Smith W, Cavanagh JB, eds. Recent advances in neuropathology. Edinburgh: Churchill Livingstone, 1982: 242-71.

3 Parks AG. Anorectal incontinence. Proc $R$ Soc Med 1975; 68: 681-90

4 Beersiek F, Parks AG, Swash M. Pathogenesis of ano-recta incontinence: a histometric study of the anal sphincter musculature. $\mathcal{F}$ Neurol Sci 1979; 42: 111-27.

5 Cerulli MA, Nikoomanesh P, Schuster MM. Progress in biofeedback conditioning for faecal incontinence. Gastroenterology 1979; 76: 742-6.

6 Engel BT, Nikoomanesh P, Schuster MM. Operant conditioning of rectosphincteric responses in the treatment of faecal ing of rectosphincteric responses in the treat

7 Wald A. Biofeedback therapy for faecal incontinence. Ann Intern Med 1981; 95: 146-9.

8 Wald A, Tunuguntla AK. Anorectal sensorimotor dysfunction in faecal incontinence and diabetes mellitus: modification with biofeedback therapy. N Engl f Med 1984; 310: 1282-7.

9 Goldenberg DA, Hodges K, Hersh T, Jinich H. Biofeedback therapy for faecal incontinence. Am $\mathcal{F}$ Gastroenterol 1980; 74: $342-5$

10 Riboli EB, Frascio M, Pitto G, Reboa G, Zanolla R. Biofeedback conditioning for faecal incontinence. Arch Phys Med Rehabil 1988; 69: 29-31

11 Whitehead WE, Burgio KL, Engel BT. Biofeedback treatment of faecal incontinence in geriatric patients. $\mathcal{f} \mathrm{Am}$ Geriatr Soc 1985; 33: 320-4.

12 Loening-Baucke V, Anuras S. Effects of age and sex on anorectal manometry. Am $\mathcal{f}$ Gastroenterol $1985 ; 80: 50-3$.

13 Schuster MM, Hookman P, Hendrix TR, Mendeloff A. Simultaneous manometric recording of internal and external anal sphincteric reflexes. Bull fohns Hopkins Hosp 1965; 116: 79-88.

14 Wald A. Use of biofeedback in treatment of faecal incontinence in patients with meningomyelocele. Pediatrics 1981;68: 45-9.

15 Loening-Baucke V. Sensitivity of the sigmoid colon and rectum in children treated for chronic constipation. IPediatr Gastroenterol Nutr 1984; 3: 454-9.

16 Loening-Baucke V. Abnormal rectoanal function in children recovered from chronic constipation and encopresis. Gastrorecovered from chronic constipat
enterology $1984 ; 87: 1299-304$

enterology $1984 ; 87: 1299-304$.
17 Haynes WG, Read NW. Ano-rectal activity in man during rectal infusion of saline: a dynamic assessment of the anal rectal infusion of saline: a dynamic assessment of

18 Whitehead WE, Parker L, Bosmajian L, et al. Treatment of faecal incontinence in children with spina bifida: Comparifaecal incontinence in children with spina bifida: Compari-
son of biofeedback and behavior modification. Arch Phys son of biofeedback and behavior

19 McHugh S, Walma K, Diamant NE. Faecal incontinence: a controlled trial of biofeedback. Gastroenterology 1986; 90: 1545 .

20 Latimer PR, Campbell D, Kasperski J. A component analysis of biofeedback in the treatment of faecal incontinence. Biofeedback Self Regul 1984; 9: 311-24.

21 Loening-Baucke V, Desch L, Wolraich M. Biofeedback training in patients with meningomyelocele and faecal incontinence. Dev Med Child Neurol 1988; 30: 781-90. 